\title{
High risk human papilloma virus (HPV) common among a cohort of women with female genital mutilation
}

\author{
Jeremiah Ogah ${ }^{1}$, Olatunji Kolawole ${ }^{1}$, Daniel Awelimobor ${ }^{2}$
}

1. Infectious Diseases and Environmental Health Research Group, Department of Microbiology, University of Ilorin. 2. Department of Pathology, Federal Medical Centre, Lokoja.

\begin{abstract}
Background: Nigeria accounts for $25 \%$ of cases of Female genital mutilation (FGM) worldwide, with increased incidence of cervical cancer.

Objective: This study was aimed at evaluating the relationship between FGM and HPV in a locality with high prevalence of FGM.

Methods: Papanicolaou test, DNA hybridization using Polymerase Chain Reaction (PCR), and flow-through hybridization was done to determine the genotypic variants of the HPV. Physical examination and questionnaires were also used to ascertain presence of FGM.

Results: FGM was found among 98(49\%) subjects, while 23(11.5\%) had one or more genotype of HPV. Majority of the cases of HPV $(78.3 \%)$ occurred in FGM subjects. Seventeen Genotypes of HPV were found among subjects with FGM consisting of 11 high risk $(16,18,31,33,35,39,52,56,73,81,82)$ and 6 low risk $(43,44,6,26,84,70)$. A correlation ( $\mathrm{p}$ value $=0.0052$ at $95 \%$ $\mathrm{CI}$ ) was found between FGM and HPV prevalence with a positive result for post hoc analysis. Results show the first reported case of quintuple HPV infection in a single subject in Nigeria.
\end{abstract}

Conclusion: FGM needs to be halted as it has no known health benefit yet may increase the risk for cervical cancer.

Keywords: HPV, female genital mutilation.

DOI: https://dx.doi.org/10.4314/ahs.v19i4.19

Cite as: Ogah J, Kolawole O, Awelimobor D. High risk human papilloma virus (HPV) common among a cohort of women with female genital mutilation. Afri Health Sci.2019;19(4):2985-2992. bttps://dx.doi.org/10.4314/abs.v19i4.19

\section{Introduction}

Human papillomavirus virus (HPV) infection is one of the most common viral sexually transmitted infections in the world. ${ }^{1}$ Persistent infection by high risk HPV have been associated with the development of cervical cancer ${ }^{2}$ and more recently oropharyngeal cancer.3 HPV prevalence rate among women with normal cytology ranges from $10 \%-26 \%{ }^{3}$ The high prevalence rate of HPV among Nigerian women leads to a corresponding risk in the increase of cervical cancer cases in Nigeria. Currently, cervical cancer is the second highest cause of cancer deaths among Nigerian women ${ }^{2}$, with 8,240 deaths occurring annually in Nigeria accounting for $49.8 \%$ and

\section{Corresponding author: \\ Jeremiah Ogah, \\ Infectious Diseases and Environmental \\ Health Research Group, Department of \\ Microbiology, University of Ilorin. \\ Email: Ogahij@yahoo.com}

$3.1 \%$ of cervical cancer related deaths in West Africa and globally respectively. ${ }^{3}$

Also, female genital mutilation (FGM) is still a common practice in Nigeria. Nigeria has the highest number of women that has undergone female genital mutilation in the world, accounting for about $25 \%$ of all cases of female genital mutilations in the world. ${ }^{4}$ With no health benefit attributed to this practice, various health complications both short term and long term have been the bane of women and children subjected to this ignoble practice. ${ }^{5}$ Some of the short term effects of FGM include severe pain, shock, hemorrhage, urinary tract infection to some long term effect such permanent damage to the female genital tissue, chronic inflammation, long life trauma and permanent damage to the urethra. ${ }^{4,5}$ Various factors such as religion, traditions, beliefs have led to increased practice of FGM. However, younger women tend not to support this harmful practice. It is worthy of note that FGM violates the fundamental human rights of women.,

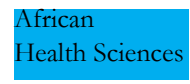

2985

(C) 2019 Ogah et al. Licensee African Health Sciences. This is an Open Access article distributed under the terms of the Creative commons Attribution License (https://creativecommons.org/licenses/BY/4.0), which permits unrestricted use, distribution, and reproduction in any medium, provided the original work is properly cited. 
Various risk factors have been associated with the prevalence of HPV and cervical cancer including smoking, parity, ${ }^{6}$ alcohol, continuous usage of steroid contraceptives. $^{7}$ Generally, the risk factors associated with HPV prevalence is largely attributed to both biological and behavioral factors. However, there are no literature linking the prevalence of HPV to FGM or considering FGM as a probable risk factor in $\mathrm{HPV}$ prevalence. However, $\mathrm{WHO}^{5}$ indicated that FGM could result in an increased risk of cervical cancer while stating that more research needed to be done.

Hence this study was carried out to determine a significant association between HPV and FGM prevalence in Ilorin, Nigeria.

\section{Materials and method Sampling}

This study was carried out in Ilorin, Kwara state. A consecutive sampling of 200 women determined using Fisher's formula for cross sectional study were surveyed for this study. The subjects also met the inclusion criteria for HPV testing including age, being sexually active, parity and subjects who have not had complete or total hysterectomy. Sampling was carried out in Ilorin in November 2016.

\section{Study population}

The study was carried out among consenting women within the ages of $15 \mathrm{yrs}$ and 60yrs (note: choice of age range starting from $15 \mathrm{yrs}$ was necessitated by the common age of first child birth in the study area which is often at 15yrs), who met the inclusion criteria, attending the Family planning clinics of Sobi Specialist Hospital, Ilorin. A structured close ended questionnaire was administered to these subjects. Informed consent was obtained from all individual participants included in the study.

\section{Data collection}

Questionnaires were administered to subjects who met the inclusion criteria. The response to the questionnaire gave information about; Socio-demographic characteristics such as age, sex, and the socioeconomic status such as level of education and occupation. It also gave information about patient's history of disease, awareness, and patient's disposition with respect to various risk factors associated with HPV and cervical cancer.

\section{Sample collection and analysis}

Cervical smears were collected using a cytobrush by a Gynecologist and immediately placed in a preservative liquid and transported to the laboratory. FGM was determined through self-report and clinical examination by a gynecologist during pap smear collection. The samples were collected and taken to the laboratory for the following analysis; Papanicolaou test, DNA hybridization using Polymerase Chain Reaction (PCR), and flow through hybridization was done to determine the genotypic variants of the HPV. For Pap test, Lituo (Liquid based cytology) was utilized instead of the conventional cytology to aid proper recovery of HPV DNA present. For Pap smear staining, the conventional staining procedure as described by Papanicolaou ${ }^{8}$ was done with cytology slides classified according to The Bethesda System for Reporting Cervical/Vaginal Cytologic Diagnose.

\section{Molecular characterization of HPV genotypes}

HPV testing was performed at Nova Diagnostics Nigeria. DNA extraction was done using DNA extraction kits (Integrated technologies, USA) according to the manufacturer's instruction. For the molecular characterization of HPV, The GenoFlow (GF) was used. GenoFlow developed by Diagcor Bioscience Inc., as the capacity of genotyping 33 types of HPV including 17 high risk (genotypes: $16,18,31,33,35,39,45,51,52,53,56,58,59$, 66, 68, 73 and 82) and 16 low risk (genotypes 6, 11, 26, $40,42,43,44,54,55,57,61,70,71,72,81$ and 84) with a universal probe to determine other variants of HPV not captured among the 33. It uses a modified PGMY primer, using it for the amplification of HPV L1 region.

PCR was performed in a thermocycler (Thermocell, China), the reaction mixture was utilized as stated by Diagcor. The reaction sequence was as follows; initial incubation at $95^{\circ} \mathrm{C}$ for $9 \mathrm{~min}$, and then went through 43 cycles of denaturation at $95^{\circ} \mathrm{C}$ for $20 \mathrm{~s}$, annealing at $55^{\circ} \mathrm{C}$ for $30 \mathrm{~s}$, elongation at $72^{\circ} \mathrm{C}$ for $30 \mathrm{~s}$. A final extension was carried out at $72^{\circ} \mathrm{C}$ for $5 \mathrm{~min}$. After amplification, hybridization was carried using the Genoflow utilizing flowthrough hybridization. This was done after rigorous washing with the hybridized DNA detected using streptavidin-alkaline phosphatase followed by colorimetric development using nitroblue tetrazolium-5-bromo-4-chloro-3-indolylphosphate (NBT-BCIP). Relationship between FGM and $\mathrm{HPV}$ infection was established using Chi-square test with a value corresponding to $\mathrm{P}<0.05$ regarded as significant. 
Using logistic regression confounding variables were equally control in establishing the relationship between FGM and HPV.

\section{Results}

The demographic activities of the study population are represented in Table 1. Majority of the women under study were Muslims, had some form of formal education and married. Results from this study shows that only 2 $(1.0 \%)$ of the subjects showed one or more form of cervical cytology abnormality. The abnormalities seen among the subjects were Low grade Squamous Intraepithelial Lesions (LSIL). Results also showed that 23 (11.5\%) subjects had one or more genotype of HPV.

Table 1: Demographic characters of the study population

\begin{tabular}{|c|c|c|}
\hline \multicolumn{2}{|c|}{ Demographic Characteristics } & \multirow{2}{*}{$\begin{array}{c}\begin{array}{c}\text { Study } \\
\text { Population } \\
(\%)\end{array} \\
12(6)\end{array}$} \\
\hline Age of subjects & 15-20years & \\
\hline & 21-30years & $128(64)$ \\
\hline & 31-40years & $56(28)$ \\
\hline & 41-50years & $4(2)$ \\
\hline & Total & $200(100)$ \\
\hline \multirow[t]{3}{*}{ Type of Education } & Formal Education & $180(90)$ \\
\hline & Informal Education & $20(10)$ \\
\hline & Total & $200(100)$ \\
\hline \multirow{6}{*}{$\begin{array}{l}\text { Highest level of } \\
\text { Education }\end{array}$} & Primary Education & $12(6)$ \\
\hline & & \\
\hline & Secondary Education & $60(30)$ \\
\hline & Tertiary Education & $108(54)$ \\
\hline & Informal Education & $20(8)$ \\
\hline & Total & $200(100)$ \\
\hline \multirow[t]{4}{*}{ Religion } & Christian & $12(6)$ \\
\hline & Muslims & $184(92)$ \\
\hline & Others & $4(2)$ \\
\hline & Total & $200(100)$ \\
\hline \multirow[t]{4}{*}{ Marital status } & Married & $196(98)$ \\
\hline & Single & $4(2)$ \\
\hline & Widow & $0(0)$ \\
\hline & Total & $200(100)$ \\
\hline
\end{tabular}

Furthermore, FGM was found among 98 (49\%) subjects with majority of the cases of HPV infection (78.3\%) found among subjects with FGM (Table 2). Similarly, the two incidence of LSIL were found to be present among subjects with FGM and the smears contained multiple genotypes of HPV. A total of 17 different genotypes of $\mathrm{HPV}$ were found in this study consisting of 11 high risk $(16,18,31,33,35,39,52,56,73,81,82)$ and 6 low risk
$(43,44,6,26,84,70)$ genotypes.. Furthermore, the results from Table 2 show that the prevalence of any HPV was higher among women with FGM compared to women without FGM [18 (78.3\%) vs. 5 (21.7\%), crude Odds Ratio $=4.37,95 \%$ Confidence Interval: 1.5520 to 12.2769 ] as was the prevalence of any HR-HPV [19 (95\%) vs. 1 $(5 \%)$, crude Odds Ratio $=12.67,95 \%$ Confidence Interval: 1.1772 to 13.6]. 
Table 2: Relationship between female genital mutilation and HPV infection

\begin{tabular}{|c|c|c|c|c|c|c|}
\hline & \multirow[t]{2}{*}{ Risk factors } & \multicolumn{2}{|c|}{$\begin{array}{l}\text { Subjects with female } \\
\text { genital mutilation }\end{array}$} & \multirow[t]{2}{*}{$X^{2}(p$ value $)$} & \multirow[t]{2}{*}{$95 \%$ CI } & \multirow[t]{2}{*}{ Odds ratio } \\
\hline & & Yes & No & & & \\
\hline \multirow{2}{*}{$\begin{array}{l}\text { HPV } \\
\text { Prevalence }\end{array}$} & Positive & 18 & 5 & \multirow{2}{*}{$7.63(0.01)$} & \multirow{2}{*}{1.56 to 12.28} & \multirow{2}{*}{4.37} \\
\hline & Negative & 80 & 97 & & & \\
\hline HPV & High Risk & 19 & 1 & $5.88(0.15)$ & 1.18 to 13.60 & 12.67 \\
\hline Genotypes & Low Risk & 6 & 4 & & & \\
\hline \multirow[t]{2}{*}{ Co-infection } & Multiple HPV infections & 9 & 2 & $0.01(0.67)$ & 0.13 to 9.61 & 1.11 \\
\hline & Single HPV infection & 10 & 2 & & & \\
\hline
\end{tabular}

$\mathrm{P}$ value $<0.005$ is statistically significant

Table 3 shows the risk factors that showed positive correlation to HPV prevalence. The relationship between HPV, FGM and these risk factors which are potential confounding variables. Risk factors with the least exposue to HPV infection were chosen as the reference groups (Table 3). Table 4 shows the relationship between FGM, $\mathrm{HPV}$ infection and confounding variables.

Table 3: Risk factors associated with HPV infection

\begin{tabular}{|c|c|c|c|c|c|}
\hline & & \multicolumn{2}{|c|}{ HPV Infection } & \multirow[b]{2}{*}{$\mathrm{X}^{2}$ (P value) } & \multirow[b]{2}{*}{ OR $(95 \% \mathrm{CI})$} \\
\hline & & Yes & No & & \\
\hline \multirow[t]{4}{*}{ Age of subjects } & 15-20years & 2 & 8 & \multirow[t]{4}{*}{$8.3(0.04)$} & \multirow[t]{4}{*}{$0.08(0.03-0.13)$} \\
\hline & 21-30years & 15 & 73 & & \\
\hline & 31-40years & 6 & 62 & & \\
\hline & 41-50years & 0 & 34 & & \\
\hline \multirow[t]{2}{*}{ Sex at an Early Age } & Yes & 17 & 80 & \multirow[t]{2}{*}{$6.72(0.01)$} & \multirow[t]{2}{*}{$0.29(0.11-0.77)$} \\
\hline & No & 6 & 97 & & \\
\hline \multirow[t]{2}{*}{ Sexual Partner Circumcised? } & Yes & 15 & 70 & \multirow[t]{2}{*}{$5.49(0.02)$} & \multirow[t]{2}{*}{$0.3489(0.14-0.87)$} \\
\hline & No & 8 & 107 & & \\
\hline \multirow{2}{*}{$\begin{array}{l}\text { Subjects in a polygamous } \\
\text { marriage? }\end{array}$} & Yes & 16 & 62 & \multirow[t]{2}{*}{$10.21(0.00)$} & \multirow[t]{2}{*}{$0.2359(0.09-0.60)$} \\
\hline & No & 7 & 115 & & \\
\hline
\end{tabular}


Table 4: Regression analysis of the relationship between HPV Infection and FGM

\begin{tabular}{|c|c|c|c|c|c|c|c|c|}
\hline \multicolumn{9}{|c|}{ Coefficients $^{\mathrm{a}}$} \\
\hline \multirow{2}{*}{\multicolumn{2}{|c|}{ Model }} & \multicolumn{2}{|c|}{$\begin{array}{l}\text { Unstandardized } \\
\text { Coefficients }\end{array}$} & \multirow{2}{*}{$\begin{array}{l}\text { Standardized } \\
\text { Coefficients } \\
\text { Beta }\end{array}$} & \multirow[t]{2}{*}{$\mathrm{t}$} & \multirow[t]{2}{*}{ Sig. } & \multicolumn{2}{|c|}{$\begin{array}{l}95.0 \% \text { Confidence Interva } \\
\text { for B }\end{array}$} \\
\hline & & $\mathrm{B}$ & $\begin{array}{l}\text { Std. } \\
\text { Error }\end{array}$ & & & & $\begin{array}{l}\text { Lower } \\
\text { Bound }\end{array}$ & Upper Bound \\
\hline \multirow[t]{2}{*}{1} & (Constant) & 1.682 & 0.071 & & 23.849 & 0.000 & 1.543 & 1.821 \\
\hline & Subjects with FGM & 0.135 & 0.044 & 0.211 & 3.037 & 0.003 & 0.047 & 0.222 \\
\hline \multirow[t]{3}{*}{2} & (Constant) & 1.480 & 0.098 & & 15.131 & 0.000 & 1.287 & 1.673 \\
\hline & Subjects with FGM & 0.134 & 0.044 & 0.209 & 3.068 & 0.002 & 0.048 & 0.219 \\
\hline & Age of subjects & 0.077 & 0.027 & 0.199 & 2.911 & 0.004 & 0.025 & 0.129 \\
\hline \multirow[t]{4}{*}{3} & (Constant) & 1.506 & 0.097 & & 15.520 & 0.000 & 1.314 & 1.697 \\
\hline & Subjects with FGM & 0.904 & 0.305 & 1.417 & 2.960 & 0.003 & 0.302 & 1.506 \\
\hline & Age of subjects & 0.074 & 0.026 & 0.189 & 2.809 & 0.005 & 0.022 & 0.125 \\
\hline & Sex at an Early Age & $\begin{array}{c}- \\
0.778\end{array}$ & 0.305 & -1.220 & -2.548 & 0.012 & -1.381 & -0.176 \\
\hline \multirow[t]{5}{*}{4} & (Constant) & 1.377 & 0.107 & & 12.843 & 0.000 & 1.166 & 1.589 \\
\hline & Subjects with FGM & 0.922 & 0.301 & 1.444 & 3.063 & 0.003 & 0.328 & 1.515 \\
\hline & Age of subjects & 0.078 & 0.026 & 0.201 & 3.028 & 0.003 & 0.027 & 0.129 \\
\hline & Sex at an Early Age & $\begin{array}{c}- \\
0.860\end{array}$ & 0.303 & -1.347 & -2.842 & 0.005 & -1.456 & -0.263 \\
\hline & $\begin{array}{l}\text { Been Wife in a } \\
\text { polygamous } \\
\text { marriage }\end{array}$ & 0.132 & 0.050 & 0.202 & 2.634 & 0.009 & 0.033 & 0.231 \\
\hline \multicolumn{9}{|c|}{ a. Dependent Variable: HPV Infection } \\
\hline
\end{tabular}

Analysis showed a minimal effect in the odds ratio of subjects with FGM in the second model when the predictor age was added. Thus age alone was not a confounding variable. However, in the models 3 and 4 when two additional predictors were added, there was a corresponding positive increase in the odds ratio of the predictors.

\section{Discussion}

This study provides a comprehensive reports on the genotypic variants of HPV present in a North Central state of Nigeria with High level prevalence rate of FGM. Majority of the subjects were found between the age of 21-30 years accounting for $128(64.0 \%)$ of the study population. This was not surprising, as sampling was done among women attending family planning clinics of the surveyed hospital. Majority of the women belonged to the child bearing age which forms the fulcrum of this study. Mbamara et al. ${ }^{9}$ Odusolu et al. ${ }^{10}$ and Schluterman et al. ${ }^{11}$, also recorded this age range as been the most prevalent in their study of HPV infection among a cohort of women. They had a prevalence rate of $52 \%, 66.6 \%$, $80.6 \%$ respectively.

Results revealed that out of the 200 women who participated in the study, 198 (99.0\%) had normal cytology (they were negative for intraepithelial lesion or malignancy), while $2(1.0 \%)$ women had abnormal cytology (they were positive for intraepithelial lesion or malignancy). The prevalence of $1.0 \%$ abnormal cytology in this study is different from that reported by Durowade et al. ${ }^{13}$ in Kwara state, which reported a prevalence rate of $5 \%$ for abnormal cytology. Although the result of $99.0 \%$ for normal cytology is higher than those reported by Adekunle and Samaila ${ }^{13}$ who reported $74.5 \%$ normal cytology, and Odusolu et al. ${ }^{10}$ who reported the prevalence of normal cytology as $83.7 \%$ it is worthy of note that majority of these studies were retrospective, and a large section of such patients were not voluntary, but patients who already had gynecological problems and cytology was recommended. This is likely going to result in higher number of abnormal cytology compared to this study which utilized normal women with no related gynecological problems. Thomas .4 reported a prevalence of $9.4 \%$ abnormality for a similar study in Ibadan.

A key feature of this study is establishing the relationship between FGM and HPV prevalence. Although no direct relationship has been drawn between HPV prevalence and FGM in the past, a significant difference existed statically ( $\mathrm{p}$ value $=0.0052,95 \%$ CI 1.5520 to 12.2769$)$. Results from the linear regression analysis carried out on Table 4 further establishes this relationship between HPV and FGM. After standardizing for age of the subjects, there was minimal effect on the odds ratio (0.135 to 0.134$)$ of 
the subjects with FGM. However, there was a significant positive change of the odds ratio to 0.904 and 0.922 after adjusting for subjects who had sex at an early age and subjects in a polygamous marriage. The high prevalence of FGM (49\%) among the subjects shows that FGM is still a common practice in Ilorin, Nigeria. It is worthy of note that this study did not seek out directly subjects with FGM, rather subjects attending family planning clinics were recruited.

It has been noted that FGM has no known health benefits (WHO, 2016) yet the health risk associated with it are numerous. It was clearly noted in this study that High risk HPV was found more commonly in subjects in subjects with FGM. The reason for this is not yet established as there is a dearth of literature focusing on the infection acquisition mechanism of women with FGM, as most studies focuses on epidemiological studies of FGM. ${ }^{16}$ The presence of abnormal cytology and higher presence of multiple HPV infections among these women with FGM further shows that FGM could be a potential risk factor in the prevalence of HPV infection and thus cervical cancer.

Results from this study showed that $11.5 \%$ of the study population had one or more HPV infection. This is relatively high as majority of these women with HPV infection had normal cytology i.e. were negative for intraepithelial lesions. While Al-Awadhi et al. ${ }^{17}$ reported a prevalence of $2.4 \%$ among women with normal cervical cytology in Kuwait, Adenis et al.18 reported a prevalence rate of $27.2 \%$ among women with normal cytology in French Guiana. Although Adenis et al.18 reiterated that the figure stated in their research was among the highest in the world.

A total of 17 different genotypes of HPV were found in this study consisting of 11 high risk $(16,18,31,33,35$, $39,52,56,73,81,82)$ and 7 low risk $(43,44,6,26,84,70)$ genotypes. The use of flow through hybridization as utilized in this study has been shown to possess the ability to identify 33 different genotypes of HPV. ${ }^{19}$ While Nyengidiki et al20 and Kolawole et al.21 obtained 4 genotypes of $\operatorname{HPV}(16,18,31,35)$ in studies in Port Harcourt and Lokoja Nigeria respectively.

Furthermore, subjects with abnormal cytology i.e. Low grade Squamous Intraepithelial Lesions (LSIL) found in this study had multiple HPV genotype. This study also reports the presence of quintuple infection of HPV (HPV
$70,33,73,81,82)$. This was found among subjects with Low grade squamous intraepithelial lesions. This is the first report on quintuple HPV infection in a single subject in Nigeria. Sharifah et al.22 obtained high risk HPV genotypic variants of $16,18,31,51,52,56,58$ and 66 , from abnormal cervical smears, with the highest frequency of genotypes occurring in LSIL smears. Thomas et al.14 obtained similar results in Ibadan, Nigeria where the common high risk HPV genotypic variants found among the subjects were 16, 31, 35 and 58. These cases of multiple infections tend to have been more common in subjects FGM. Other factors such as age of the subjects, being in a polygamous marriage and sexual partner circumcision all had a statistical relationship with HPV prevalence. These factors have been previously established as potential risk factors for HPV infection and cervical cancer. ${ }^{2}$ Thus focus was not placed on their individual ability to increase HPV prevalence, but as confounding variables as shown in Table 4.

While the relationship between cervical cancer, FGM and HPV infection is still not well understood. Some studies have also drawn a relationship between FGM and invasive cervical cancer. Osterman ${ }^{23}$ reported that in their analysis of Senegalese women with and without cervical abnormalities and invasive cancer, a strong association between FGM and invasive cervical cancer was found. It is not exactly clear while subjects with FGM are more likely to develop cervical cancer but a look at the oncogenic mechanisms of most cancerous cells has shown a direct correlation between inflammation which is a primary defense mechanism by the body against infections and carcinogenesis. ${ }^{24}$ Sexually transmitted infections such as HPV, herpes simplex type are known to also induce inflammatory response. ${ }^{25}$ With chronic inflammation one of the prolonged effect of FGM, it thus can be argued that women with FGM especially those with chronic inflammatory responses are more likely to develop cervical cancer. Furthermore, studies have shown that FGM increases the risk of having bacterial vaginosis $(\mathrm{BV}){ }^{26}$ Morrison et al26 in their study of the long term effect of FGM among a rural community in Gambia noted that women with FGM had a higher prevalence of BV at an adjusted odds ratio $(\mathrm{OR})=1.66 ; 95 \%$ confidence interval (CI) 1.25-2.18. This is important because different studies have shown that the presence of BV among subjects significantly increases their risk of acquiring HPV in- 
fection. While the actual mechanism is not known, this strong correlation cannot be overlooked. ${ }^{27,28,29}$ Thus one can imply that FGM which significantly increases the risk of genital inflammation as well as BV, invariably increases the risk of acquiring HPV infection and thus cervical cancer. Also, a link has been established between HPV infection and BV in women. Studies have shown that BV which is characterized by low level of Lactobacillus spp, increased prevalence of anaerobes, ${ }^{30}$ is linked with persistent HPV infection and developing precancerous lesions. ${ }^{31,32}$ Although it was observed in this study that the two subjects already developing cervical neoplasia had high risk HPV, the data is too small to make any conclusion from that.

This study clearly establishes a statistical correlation between HPV and FGM prevalence. However, there is a need to take a further look at the role other risk factors associated with HPV infection play vis-à-vis FGM among a cohort of women with only FGM. Meanwhile there is a need to increase the awareness of Nigerians about the dangers of FGM in other to curb this abuse that is still be perpetuated against women in Nigeria.

\section{Limitation of study}

The type of FGM the subjects had were not considered. This could be relevant in understanding cervical cancer pathogenesis.

\section{Conflict of interest}

None declared.

\section{References}

1. WHO. (2014). www.who.int/pmnch/media/ events/2014/africa_cancer_mortality.pdf

2. Kolawole OM, Ogah IJ, Alabi O, Suleiman MM, Amuda OO, Kolawole CF. (2015). Utilization of Human Papillomavirus DNA Detection for Cervical Cancer Screening In Women Presenting With Abnormal Cytology In Lokoja, Nigeria. Judishapur Journal of Microbiology. 8(10): e22620. DOI: $10.5812 /$ jjm.22620

3. Bruni L, Barrionuevo-Rosas L, Albero G, Serrano B, Mena M, Gómez D, Muñoz J, Bosch FX, de Sanjosé S. (2017). ICO Information Centre on HPV and Cancer (HPV Information Centre). Human Papillomavirus and Related Diseases in Nigeria. Summary Report 19 April 2017. http://www.hpvcentre.net/statistics/reports/NGA.pdf Accessed 19th June, 2017.
4. Okeke TC, Anyaehie USB, Ezenyeaku CCK. (2012). An Overview of Female Genital Mutilation in Nigeria. Ann Med Health Sci Res. 2(1): 70-73.doi: 10.4103/21419248.96942

5. WHO (2012). Understanding and addressing violence against women: Female genital mutilation. http:/ / apps.who.int/iris/bitstream/10665/77428/1/WHO_ RHR_12.41_eng.pdf Accessed 19 ${ }^{\text {th }}$ June, 2017.

6. Kolawole OM, Olatunji KT, Durowade KA. (2016). Molecular detection of human papillomavirus from abnormal cervical cytology of women attending a tertiary health facility in Ido-ekiti, southwest Nigeria. J Prev Med Hyg. 57: E86-E90

7. Zitkute V, Bumbuliene Z. (2016). Risk Factors Affecting HPV Infection, Persistence and Lesion Progression in Women and Men. Clin Res Infect Dis. 3(2): 1026.

8. Papanicolaou GN. (1943). A New Procedure for Staining Vaginal Smears. Science. 95(2469): 438-439.

9. Mbamara SU, Ukah CO, Ikpeze O, Okonkwo J, Onyiaora V. (2011). Correlation between visual inspection of the cervix and pap smear test for cervical cancer screening. Journal of Cancer Research and Experimental Oncology. 3(1): 8-13.

10. Odusolu PO, Omotoso AJ, Nnoli M, Agan TU, Bassey IE, Ekanem IA, Ekanem AD. (2013). Pattern of Cervical Smear Cytology in Calabar, Nigeria. Journal of VLSI and Signal Processing 2(6):37-41.

11. Schluterman NH, Sow SO, Traore CB, Bakarou K, Dembelé R, Sacko F, Gravitt PE, Tracy JK. (2013). Differences in patterns of high-risk human papillomavirus infection between urban and rural low-resource settings: crosssectional findings from Mali. BioMed Central Women's 13:4-13.

12. Durowade KA, Osagbemi GK, Salaudeen AG, Musa OI, Akande, TM, Babatunde OA, Raji HO, Okesina BS, Fowowe AA, Ibrahim OOK and Kolawole OM (2012). Prevalence and risk factors of cervical cancer among women in an urban community of Kwara State, North Central Nigeria. Journal of Preventive Medicine and Hygiene 53: 213-219.

13. Adekunle OO, Samaila MOA (2010). Prevalence of cervical intraepithelial neoplasia in Zaria. Annals of African Medicine 9(3):194-195

14. Thomas JO, Herrero R, Omigbodun AA, Ojemakinde K, Ajayi IO, Fawole A, Oladepo O, Smith JS, Arslan A, Munoz N, Snijders PJ, Meijer CJ, Franceschi S. (2004). Prevalence of papillomavirus infection in women 
in Ibadan, Nigeria: a population-Based study. British Journal Cancer 90: 638-645.

15. WHO (2016). WHO guidelines on the management of health complications from female genital mutilation. http://apps.who.int/iris/bitstre am/10665/206437/1/9789241549646_eng.pdf Accessed 19th June, 2017.

16. Reisel D, Creighton SM. (2015). Long term health consequences of Female Genital Mutilation (FGM). Maturitas 80 (2015) 48-51

17. Al-Awadhi R, Chehadeh W, Kapila K. (2011). Prevalence of human papillomavirus among women with normal cervical cytology in Kuwait. J Med Virol 83(3):453-60. doi: 10.1002/jmv.21981.

18. Adenis A, Dufit V, Douine M, Najioullah F, Molinie V, Catherine D, Kilié O, Thomas N, Deshayes J, Brousse P, Amor HB, Pignoux R, Carles G, Grenier C, Lacoste V, Cesaire R, Nacher M. (2017). The singular epidemiology of HPV infection among French Guianese women with normal cytology. BMC Public Health 17: 279.

19. Wong FK, Ching CY, Chow JKF, (2010). Comparison of the DiagCor GenoFlow Human Papillomavirus Array Test and Roche Linear Array HPV Genotyping Test. The Open Virology 4:169-174

20. Nyengidiki TK, Durugbo I, Goddy B. (2016). Risk factors and distribution of oncogenic strains of human papilloma virus in women presenting for cervical cancer screening in Port Harcourt, Nigeria. Pan African Medical Journal 23:85 doi:10.11604/pamj.2016.23.85.8510

21. Kolawole OM, Ogah JI, Alabi O, Suleiman MM, Amuda OO, Kolawole CF. (2015). Utilization of Human Papillomavirus DNA Detection for Cervical Cancer Screening In Women Presenting With Abnormal Cytology In Lokoja, Nigeria. Judishapur Journal of Microbiology 8(10): e22620.

22 . Sharifah N, Seeni A, Nurismah MI, Clarence-Ko CH, Hatta AZ, Ho N, Rafaee T, Adeeb N, Jamal AR. (2009). Prevalence of Human Papillomavirus in Abnormal Cervical Smears in Malaysian Patients. Asian Pacific Journal of Cancer Prevention. 10: 303-306.

23. Osterman AL. (2016). Female genital mutilation and non-invasive cervical abnormalities and invasive cancer in Senegal, West Africa: A retrospective study. A thesis Submitted in partial fulfillment of the Requirements for the degree of Master of Public Health University of Washington 2016
24. Okada F. (2014). Inflammation-related carcinogenesis: current findings in epidemiological trends, causes and mechanisms. Yonago Acta Med 57(2):65-72.

25. Schetter AJ, Heegaard NH, Harris CC. (2010) Inflammation and cancer: interweaving microRNA, free radical, cytokine and p53 pathways. Carcinogenesis 31(1):37-49.

26. Morison L, Scherf C, Ekpo G, Katie P, Beryl W, Rosalind C, Gijs W. (2001). The long-term reproductive health consequences of female genital cutting in rural Gambia: a community-based survey. Tropical Medicine and International Health. 6(8):643-653

27. da Silva CS, Adad SJ, Hazarabedian de Souza MA. Macêdo Barcelos AC, Sarreta Terra AP, Murta EF. 2004. Increased frequency of bacterial vaginosis and Chlamydia trachomatis in pregnant women with human papillomavirus infection. Gynecol Obstet Invest. 58:189-193. doi: 10.1159/000079822.

28. Watts DH, Fazzari M, Minkoff H, Hillier SL, Sha B, Glesby M, Levine AM, Burk R, Palefsky JM, Moxley M, Ahdieh-Grant L, Strickler HD. (2005). Effects of bacterial vaginosis and other genital infections on the natural history of human papillomavirus infection in HIV-1-infected and high-risk HIV-1-uninfected women. J Infect Dis. 191:1129-1139. doi: 10.1086/427777.

29. Mao C, Hughes JP, Kiviat N, Kuypers J, Lee SK, Adam DE, Koutsky LA. (2003). Clinical findings among young women with genital human papillomavirus infection. American Journal of Obstetrics and Gynecology. 188:677684. doi: $10.1067 / \mathrm{mob} .2003 .164$.

30. Hill GB. (1993). The microbiology of bacterial vaginosis. Am J Obstet Gynecol. 169(2 Pt 2):450-454. doi: 10.1016/0002-9378(93)90339-K

31. Mitra A, MacIntyre DA, Marchesi JR, Lee YS, Bennett PR, Kyrgiou M. (2016). The vaginal microbiota, human papillomavirus infection and cervical intraepithelial neoplasia: what do we know and where are we going next? Microbiome. 4:58. doi: 10.1186/s40168-016-0203-0. [PMC free article] [PubMed] [CrossRef]

32. Song D, Kong WM, Zhang TQ, Jiao SM, Chen J, Han C, Liu TT. (2017). The negative conversion of high-risk human papillomavirus and its performance in surveillance of cervical cancer after treatment: a retrospective study. Arch Gynecol Obstet. 295:197-203. doi: 10.1007/ s00404-016-4197-4. [PubMed] [CrossRef] 